\title{
Suppression of A549 cell proliferation and metastasis by calycosin via inhibition of the PKC- $\alpha /$ ERK1/2 pathway: An in vitro investigation
}

\author{
XU-DONG CHENG ${ }^{1}$, JUN-FEI GU ${ }^{2,3}$, JIA-RUI YUAN ${ }^{2,3}$, LIANG FENG $^{2,3}$ and XIAO-BIN JIA ${ }^{2,3}$ \\ ${ }^{1}$ Pharmacy Department, Suzhou Traditional Chinese \& Western Medicine Hospital, Suzhou, Jiangsu 215101; \\ ${ }^{2}$ Key Laboratory of New Drug Delivery System of Chinese Materia Medica, \\ Jiangsu Provincial Academy of Chinese Medicine, Nanjing, Jiangsu 210028; ${ }^{3}$ College of Pharmacy, \\ Nanjing University of Chinese Medicine, Nanjing, Jiangsu 210046, P.R. China
}

Received December 4, 2014; Accepted August 24, 2015

DOI: $10.3892 / \mathrm{mmr} .2015 .4449$

\begin{abstract}
The migration and invasion of lung cancer cells into the extracellular matrix contributes to the high mortality rates of lung cancer. The protein kinase $\mathrm{C}$ (PKC) and downstream signaling pathways are important in the invasion and migration of lung cancer cells. Calycosin (Cal), an effector chemical from Astragalus has been reported to affect the recurrence and metastasis of cancer cells via the regulation of the protein expression of matrix metalloproteinases (MMPs). The inhibition of Cal on the migration and invasion of A549 cells was investigated in the present study. Cell viability and apoptosis assays were performed using MTT and flow cytometric analyses. A wound healing assay and Transwell invasion assay were performed to evaluate the effect of Cal on A549 cell migration and invasion. Invasion-associated proteins, including MMP-2, MMP-9, E-cadherin (E-cad), integrin $\beta 1$, PKC- $\alpha$ and extracellular signal-regulated kinase 1/2 (ERK1/2) were detected using western blotting. In addition, PKC- $\alpha$ inhibitor, AEB071, and ERK1/2 inhibitor, PD98059, were used to determine the association between the suppression of PKC- $\alpha$ /ERK1/2 and invasion, MMP-2, MMP-9, E-cad and integrin $\beta 1$. Cal was observed to suppress cell proliferation and induce apoptosis. There were significant differences between the phorbol-12-myristate-13-acetate (TPA)-induced A549 cells treated with $\mathrm{Cal}$ and the untreated cells in the rates of migration and invasion. The levels of MMP-2, MMP-9, E-cad and integrin $\beta 1$ in the TPA-induced A549 cells changed markedly, compared with the untreated cells. In addition, the suppression
\end{abstract}

Correspondence to: Professor Xiao-Bin Jia, Key Laboratory of New Drug Delivery System of Chinese Materia Medica, Jiangsu Provincial Academy of Chinese Medicine, 100 Shizi Street, Hongshan Road, Nanjing, Jiangsu 210028, P.R. China

E-mail: jxiaobin2005@hotmail.com

Key words: calycosin, protein kinase C- $\alpha /$ extracellular signal-regulated kinase $1 / 2$, lung cancer, invasion, migration of Cal was affected by the PKC inhibitor, AEB071, an ERK1/2 inhibitor, PD98059. The results of the present study indicated that $\mathrm{Cal}$ inhibited the proliferation, adhesion, migration and invasion of the TPA-induced A549 cells. The Cal-induced repression of PKC- $\alpha / \mathrm{ERK} 1 / 2$, increased the expression of E-Cad and inhibited the expression levels of MMP-2, MMP-9 and integrin $\beta 1$, which possibly demonstrates the mechanism underlying the biological anticancer effects of Cal.

\section{Introduction}

Lung cancer is the life-threatening disease and is the leading cause of mortality among malignant tumors worldwide (1). Of all lung cancer cases, $~ 85 \%$ develop into non-small cell lung cancer (NSCLC), with a 5-year survival rate that remains low at $18 \%$, despite developments in systemic therapy, including surgery, radiotherapy and chemotherapy, in the previous decades (2). Based on clinical observations, the lack of effective treatment for relapse and invasion of lung cancer has become a major obstacle in improving survival rates (3). Accumulative data have demonstrated that the effort of controlling the metastasis-associated pathways may delay the progression of NSCLC (4-6). Therefore, it is necessary to identify effective and safe drugs to treat NSCLC invasion and metastasis.

It has been reported that Chinese medicine benefits patients with NSCLC via increasing therapeutic effects and reducing radiotherapy toxicity in clinical studies (7-9). Calycosin (Cal) is a purified isoflavone with a defined chemical structure (Fig. 1A) and is isolated from the traditional Chinese herbs, Astragalus membranaceus (Fisch.) Bge. or Astragalus membranaceus (Fisch.) Bge. var. mongholicus (Bge.) Hsiao (10). Cal has been reported to have various pharmacologic effects with antitumor, neuroprotective and anti-inflammatory properties (11-14). Previous studies have demonstrated that Cal inhibits cancer growth via apoptosis in 143B osteosarcoma cells and MCF-7 breast cancer cells $(15,16)$. However, the antitumor activities of Cal on NSCLC metastasis and invasion, and the underlying mechanism remains to be elucidated. Therefore, the present study 
examined the A549 human lung adenocarcinoma cell line to further understand the effect of $\mathrm{Cal}$ on the migration and invasion of these cells.

PKC- $\alpha$ is a member of the PKC family, which can be activated by calcium and the second messenger, diacylglycerol (17). PKC- $\alpha$ is involved in diverse cellular signaling pathways and cellular functions, including cell proliferation, differentiation, apoptosis and survival (18). PKC- $\alpha$ serves as a major receptor for phorbol-12-myristate-13-acetate (TPA), a class of tumor promoter (19). The overexpression of PKC- $\alpha$, induced by TPA, promotes the migration and invasion of GBM8401 glioma cells (20). Previous studies have demonstrated that inhibition of the expression of PKC- $\alpha$ decreases hepatocellular carcinoma cell invasion and breast cancer metastasis $(21,22)$. The results of these studies indicate that there is a correlation between PKC- $\alpha$ and cancer cell metastasis. However, whether PKC- $\alpha$ is involved in human lung cancer cells remains to be elucidated. Therefore, the present study investigated whether PKC- $\alpha$ is involved in the inhibition of A549 cell migration and invasion by Cal.

Extracellular signal-regulated protein kinase (ERK)1/2, one of the important members of the mitogen-activated protein kinase (MAPK) family, is an essential signaling pathway by which cell survival, differentiation, apoptosis, proliferation, migration and invasion are regulated (23). Previous studies have reported that activated ERK1/2 signaling due to phosphorylation induces cancer cell proliferation, migration and invasion (24). Studies have demonstrated that Cal interacts with estrogen receptors on the cell membrane and modulates the MAPK signaling pathway to inhibit growth and induce apoptosis of ER-positive breast cancer cells $(25,26)$. It has also been demonstrated that the phosphorylation of ERK1/2 contributes to lung cancer migration and invasion (27). Therefore, the present study also aimed to investigate whether Cal inhibits lung cancer migration and invasion by regulating the ERK1/2 signal pathway, as well as its downstream biomarkers.

The present study aimed to investigate the antimetastic activity of Cal on A549 cells by assessing migration and invasion abilities and the expression levels of potential pathway proteins. The results may reveal the possible mechanisms underlying the effects of Cal on A549 cells and may provide a basis for the safety and anticancer efficacy of Cal in further clinical applications.

\section{Materials and methods}

Chemicals and reagents. Cal $\left(\mathrm{C}_{16} \mathrm{H}_{12} \mathrm{O}_{5}\right)$ was obtained from Standard Biotech Co., Ltd (Shanghai, China). The A549 human lung adenocarcinoma cell line was purchased from American Type Culture Collection (Manassas, VA, USA). TPA and bovine serum albumin (BSA) were provided by Sigma-Aldrich (St. Louis, MO, USA). Transwell chambers were purchased from Corning Incorporated (Corning, NY, USA). MMP2, MMP-9, E-cadherin (E-Cad), integrin $\beta 1$, PKC- $\alpha$ antibodies were obtained from Boster Systems, Inc. (Pleasanton, CA, USA). AEB071, a PKC- $\alpha$ inhibitor, was provided by Sellek Chemicals (Houston, TX, USA). The ERK1/2 inhibitor (PD98059), penicillin/streptomycin, trypsin, EDTA, RNase, $1 \%$ Triton X-100, SDS-PAGE gel $(10 \%)$ and polyvinylidene difluoride (PVDF) membranes were purchased from Beyotime Institute of Biotechnology (Jiangsu, China). AnnexinV/ propidium iodide (PI) was provided by Immunotech (Marseille, France). Basal Dulbecco's modified Eagle's medium (DMEM) and fetal bovine serum (FBS) were purchased from Gibco Life Technologies (Carlsbad, CA, USA). Crystal violet, acetic acid and pure methanol were purchased from Aladdin Shanghai Biochemical Technology Co., Ltd.(Shanghai, China). Other reagents used were of analytical grade and obtained from commercial sources.

Cell culture. DMEM supplemented with $10 \%$ FBS, $1 \%$ nonessential amino acids, $100 \mathrm{U} / \mathrm{ml}$ penicillin and $100 \mu \mathrm{g} / \mathrm{ml}$ streptomycin were used as the medium for A549 cell cultivation. The medium was replaced every 2 days. The incubation conditions were maintained at $37^{\circ} \mathrm{C}$ with a humidified atmosphere of $5 \% \mathrm{CO}_{2}$.

\section{3-(4,5-dimethylthiazol-2-yl)-2,5-diphenyltetrazoliumbromide} (MTT) assay for cell viability. The cell viability inhibiting effect of Cal on the A549 cells was determined using an MTT assay. Briefly, the logarithmic growth phase A549 cells were digested in $0.1 \%$ trypsin, DMEM supplemented with $10 \%$ FBS was added, and the cells were plated in 96-well plates at a final density of $0.6 \times 10^{4}$ cells/well. The cells were treated with a series of diluted concentrations of Cal (10, 20, 30, 40, 50, 60, $70,80$ or $90 \mu \mathrm{M})$ and incubated at $37^{\circ} \mathrm{C}$ for $24 \mathrm{~h}$. Following incubation, MTT $(5 \mathrm{mg} / \mathrm{ml}, 10 \mu \mathrm{l})$ solution was added to each well and incubated for $4 \mathrm{~h}$ at $37^{\circ} \mathrm{C}$. Subsequently, the supernatant in each well was discarded and dimethylsulfoxide (DMSO; $100 \mu \mathrm{l}$ ) was added. The optical density (OD) value at $570 \mathrm{~nm}$ was measured using a Spectra Max 190 microplate reader (Molecular Devices, Sunnyvale, CA, USA). Cell viability was determined by the OD value, and was calculated as the percentage of viable cells. The measurement was performed in three independent experiments.

Flow cytometric analysis. The A549 cells (6x105/well) were seeded into 6-well plates and treated with different concentration of Cal $(20,30$ and $40 \mu \mathrm{M})$, which were then cultured at $37^{\circ} \mathrm{C}$ for $24 \mathrm{~h}$. The cells were collected and digested with $0.25 \%$ trypsin and $0.02 \%$ EDTA $(1: 1)$ at $37^{\circ} \mathrm{C}$ for $3-4 \mathrm{~min}$. The cells were then pipetted gently and collected and centrifuged at $112 \mathrm{~g}$ at room temperature for $5 \mathrm{~min}$. Subsequently the cells were washed with cold phosphate-buffered saline (PBS; 0.01 M; $\mathrm{pH}$ 7.4) twice and resuspended in the residual PBS. Following the addition of $1 \mathrm{ml}$ pre-chilled $\left(-20^{\circ} \mathrm{C}\right) 80 \%$ ethanol, the cells were stored at $-20^{\circ} \mathrm{C}$ overnight. Following washing twice with PBS, 60-80 $\mu$ l RNAase $(1 \mathrm{mg} / \mathrm{ml})$ was added, and the cells incubated at $37^{\circ} \mathrm{C}$ for $30 \mathrm{~min}$. Following chilling on ice for 2 min, Annexin V-fluorescein isothiocyanate (FITC)/PI solution (100 mg/l PI, 0.1\% TritonX-100) was added, and the sample was incubated in the dark at room temperature for $30 \mathrm{~min}$. Cell apoptosis was analyzed using an FC 500 flow cytometer (Beckman Coulter, Brea, CA, USA). Data were acquired by the RXP software of the machine.

Adhesion analysis. A cell adhesion experiment was performed in 96-well plates coated with Matrigel (BD Biosciences, Franklin Lakes, NJ, USA) and air dried in a Logic ${ }^{+}$laminar hood (Labconco, Kansas City, MO, USA) overnight. The wells 
were blocked with $2 \% \mathrm{BSA}(50 \mu \mathrm{l} /$ well $)$ and incubated at $37^{\circ} \mathrm{C}$ for $2 \mathrm{~h}$. The A549 cells were stimulated with $80 \mathrm{nM}$ TPA, as described previously (28). Subsequently, the cells were treated with different concentrations of $\mathrm{Cal}(20,30$ and $40 \mu \mathrm{M})$ for $24 \mathrm{~h}$. Then cells were inoculated into the 96 -well plate at a concentration of $1 \times 10^{4}$ cells/well and incubated at $37^{\circ} \mathrm{C}$ for $30 \mathrm{~min}$. The non-adherent cells were removed with $200 \mu 1$ PBS (pH 7.4) following incubation. Subsequently, the adherent cells in each well were stained with $0.1 \%$ crystal violet and lysed with $30 \%$ acetic acid, and measured optical density at $550 \mathrm{~nm}$ on the Spectra Max 190 microplate reader. The adhesion rate was calculated from the OD values of triplicate experiments.

Wound healing analysis. A scratch assay was performed, as described previously. Briefly, the A549 cells were detached using $0.1 \%$ trypsin and resuspended in serum-free DMEM, seeded at a concentration of $5 \times 10^{6}$ cells $/ \mathrm{cm}^{2}$ into 6-well plates in the medium containing 10\% FBS. Following overnight incubation at $37^{\circ} \mathrm{C}$, a cell-monolayer was yielded for a wound healing assay. To introduce the wound, three wound tracks were scored in the monolayer, $\sim 5 \mathrm{~mm}$ in distance, in each well using a $200 \mu \mathrm{l}$ pipette tip. The suspended cells were washed twice with DMEM, and the wounded cell monolayer was incubated in FBS-free medium containing different concentrations of Cal $(20,30$ and $40 \mu \mathrm{M})$, stimulated with $80 \mathrm{nM}$ TPA, at $37^{\circ} \mathrm{C}$ for $24 \mathrm{~h}$. Images of the wound area were captured at 0 and $24 \mathrm{~h}$ using an IX73 microscope (Olympus Corporation, Tokyo, Japan). The areas in the scratch wound, which were not covered in cells were quantified using ImageJ 2.1.4.7 software (Media Cybernetics, Inc., Rockville, MD, USA). The closure rate was determined as the percentage of the area at $0 \mathrm{~h}$. The experiments were performed in triplicate.

Cell migration analysis. To determine cell migration, experiments were performed using Transwell chambers. The A549 cells were stimulated with TPA and incubated in the presence or absence of various concentrations of Cal $(20,30$ and $40 \mu \mathrm{M})$ for $24 \mathrm{~h}$. Following incubation, the cells were detached using trypsin and resuspended in serum-free medium. Medium containing $10 \%$ FBS was added to the lower chamber as a chemotactic factor, and the cells were seeded in the upper chamber at a density of $1 \times 10^{4}$ cells/well in $50 \mu 1$ serum-free medium. Following incubation for $8 \mathrm{~h}$ at $37^{\circ} \mathrm{C}$, any A549 cells, which did not penetrate the polycarbonate membrane were removed using cotton swabs. The cells, which had penetrated through membrane were fixed with methanol and stained with $0.1 \%$ crystal violet for $10 \mathrm{~min}$. The chambers were visualized in six randomly-selected visual fields under an IX73 microscope, in which the number of cells were counted. Each experiment was performed in triplicate.

Cell invasion analysis. To determine cell invasion, experiments were performed in Transwell chambers coated with Matrigel, as described previously (29). Briefly, $50 \mu \mathrm{l}$ Matrigel was coated on the membrane at the base of the Transwell chamber and air dried in a Logic ${ }^{+}$laminar hood (Labconco) overnight. Following blocking with $2 \%$ BSA ( $50 \mu \mathrm{l} /$ well), the chambers were incubated at $37^{\circ} \mathrm{C}$ for $2 \mathrm{~h}$ and were then rinsed with PBS. The cells, which had been exposed to different concentration $\mathrm{Cal}(20,30$ and $40 \mu \mathrm{M})$ were placed into the upper layer of the Transwell chamber at a concentration of $2 \times 10^{4}$ cells/well. The medium (600 $\mu \mathrm{l} /$ well) containing chemotactic factor (10\% FBS) was added to the lower layer of the Transwell chamber. The cells were cultured at $37^{\circ} \mathrm{C}$ for $24 \mathrm{~h}$. Cotton swabs were used to remove the cells, which did not penetrate the polycarbonate membrane. The cells, which penetrated through and adhered to the membrane were fixed with methanol and stained with $0.1 \%$ crystal violet for $10 \mathrm{~min}$. Following the crystal violet staining, the cells were rinsed with distilled water to removing excess dye. Subsequently six randomly-selected visual fields in each well were selected and visualized under an IX73 microscope. The number of cells that penetrated the membrane were counted, and the invasion rate was quantified by the number of permeated cells associated with the OD value. Each experiment was repeated three times.

Western blot analysis. To analyze the expression levels of migration-associated proteins in the A549 cells affected by $\mathrm{Cal}$, western blot analysis was performed. Briefly, analyses were performed following stimulation with TPA and treatment with Cal $(20,30$ or $40 \mu \mathrm{M})$, and with or without the PKC inhibitor (AEB071) or ERK1/2 inhibitor (PD98059), following TPA stimulation and Cal $(30 \mu \mathrm{M})$ treatment. The A549 cells were suspended in $250 \mu 1$ lysis buffer, containing $25 \mathrm{mM}$ Tris- $\mathrm{HCl}$ (pH 7.6), $150 \mathrm{mM} \mathrm{NaCl}, 1 \% \mathrm{NP}-40,0.1 \%$ SDS, $1 \%$ sodium deoxycholate and protease inhibitors (Thermo Fisher Scientific, Waltham, MA, USA). The cell lysate was centrifuged at $10,000 \mathrm{~g}$ for $20 \mathrm{~min}$ at $4^{\circ} \mathrm{C}$. Equal quantities of proteins from each sample $(50 \mu \mathrm{g})$ were subjected to $10 \%$ sodium-dodecyl sulfate (SDS)-polyacrylamide gel electrophoresis. The proteins were then transferred onto PVDF membranes and the membranes were blocked with $5 \%(\mathrm{w} / \mathrm{v})$ BSA for $2 \mathrm{~h}$ and washed in Tris-buffered saline with Tween 20 (TBST) three times. Subsequently, the membranes were incubated with the following primary detection antibodies: E-Cad, integrin $\beta 1$, MMP-2, MMP-9, PKC- $\alpha$, ERK1/2 and phosphorylated (p)-ERK1/2 $(1: 1,000)$ overnight at $4{ }^{\circ} \mathrm{C}$. The membranes were then washed and incubated with horseradish-peroxidase-conjugated $\operatorname{IgG}$ for $1 \mathrm{~h}$ at room temperature and then washed in TBST three times. Chemiluminescence reagents of western blotting were added for visualization of the protein bands, and quantification of the proteins bands was performed using ImageJ software.

Statistical analysis. All data in the present study were obtained from three independent experiments and are expressed as the mean \pm standard deviation. One-way analysis of variance was used for multiple comparisons and Student's $t$ test was used to evaluate the differences between two groups. All analyses were performed using SPSS 17.0 software (SPSS, Inc., Chicago, IL, USA). $\mathrm{P}<0.05$ was considered to indicate a statistically significant difference.

\section{Results}

Cal inhibits the viability of A549 cells. The effect of Cal on cell viability was assessed using an MTT assay. The A549 cells were treated with increasing doses $(0-90 \mu \mathrm{M})$ of $\mathrm{Cal}$ for $24 \mathrm{~h}$. As shown in Fig. 1B, following exposure to $\mathrm{Cal}$, the viability of 
A<smiles>COc1ccc(-c2coc3cc(O)ccc3c2=O)cc1O</smiles>

C

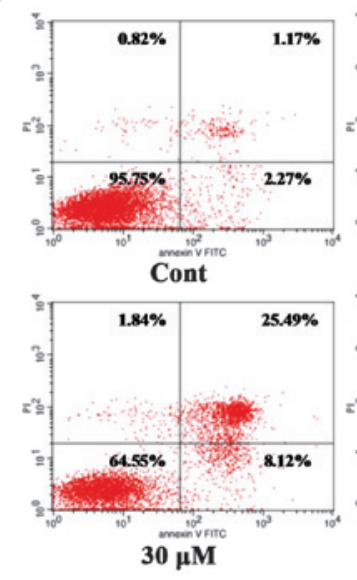

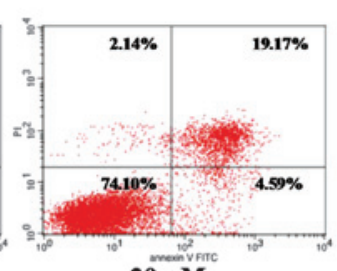

$20 \mu \mathrm{M}$

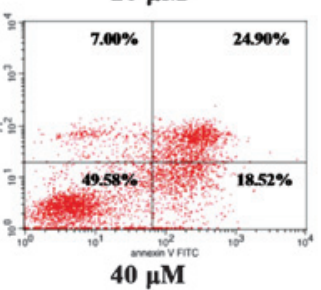

B

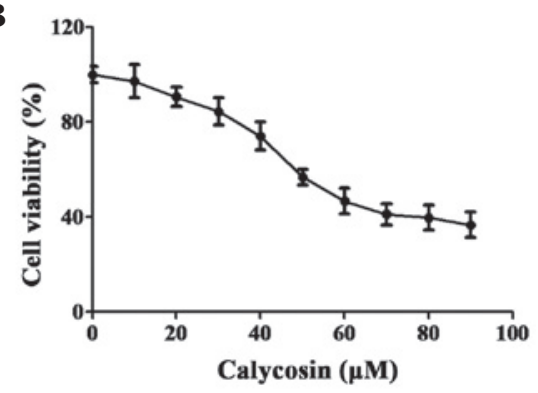

D

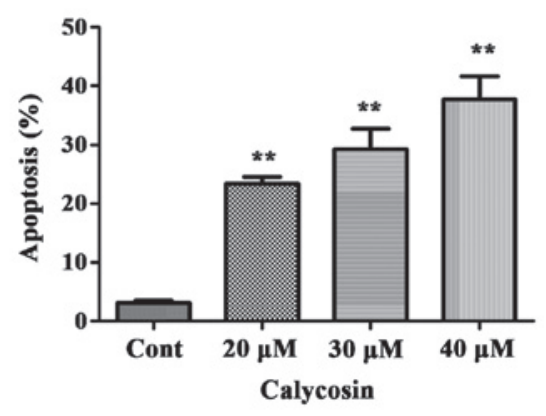

Figure 1. Effect of Cal on the proliferation and apoptosis of A549 cells. (A) Chemical structure of Cal. (B) A549 cells were treated with Cal at various concentrations $(0,10,20,30,40,50,60,70,80$ and $90 \mu \mathrm{M})$ for $24 \mathrm{~h}$, and cell viability was measured using an MTT assay. The results are expressed as a percentage of the control and presented as the mean \pm standard deviation $(\mathrm{n}=6)$. (C) A549 cells were treated with Cal $(20,30$ and $40 \mu \mathrm{M})$ and incubated for $24 \mathrm{~h}$. The control group received the same volume of dimethyl sulfoxide. Apoptotic cells were detected using Annexin V and PI staining. (D) Apoptotic rate obtained from three independent experiments and presented the mean \pm standard deviation $(n=3) .{ }^{* *} \mathrm{P} \leq 0.01$, vs. control. Cal, calycosin; Cont, control; PI, propidium iodide; FITC, fluorescein isothiocyanate.

A549 cells decreased in a dose-dependent manner. No significant change in cell viability were observed, compared with the $0 \mu \mathrm{M}$ (DMSO treatment only) group, following $24 \mathrm{~h}$ treatment with $\mathrm{Cal}$ at concentration between 0 and $40 \mu \mathrm{M}$, indicating that $\mathrm{Cal}$ was not toxic to the A549 cells at these concentrations. Following treatment with Cal at concentrations $>40 \mu \mathrm{M}$, cell viability reduced significantly at $24 \mathrm{~h}$. These results indicated that treatment with Cal at doses $>50 \mu \mathrm{M}$ for $24 \mathrm{~h}$ resulted in the dose-dependent loss of cell viability in the A549 cells, however, doses $<40 \mu \mathrm{M}$ for $24 \mathrm{~h}$ did not cause cytotoxicity. Therefore, concentrations of $\mathrm{Cal}<40 \mu \mathrm{M}$ was selected for the subsequent experiments.

Effect of Cal on cell apoptosis. To understand whether the effect of Cal on A549 cell proliferation had any association with apoptotic rates, the binding of Annexin V to phosphatidylserine, exposed on the cell membrane, was measured, which is generally recognized as an early indicator of apoptosis. As shown in Fig. 1C and D, the total percentages of Annexin V+/PI- cells (right lower quadrant representing early apoptosis) and Annexin V+/PI+ cells (right upper quadrant representing late apoptosis and necrosis) increased between 23.39 and $43.77 \%$ following treatment of A549 cells with Cal at 20,30 and $40 \mu \mathrm{M}$ for $24 \mathrm{~h}$, compared with $3.44 \%$ apoptosis in the control group. These data indicated that $\mathrm{Cal}$ induced A549 cell apoptosis in a dose-dependent manner, which was associated with the inhibition of proliferation.

Cal suppresses A549 cell adhesion induced by TPA. To investigate the inhibition of Cal on TPA-treated A549 cell adhesion, a cell matrix adhesion assay was performed. As shown in (Fig. 2A), following treatment with $\mathrm{Cal}$ at concentrations of 20, 30 and $40 \mu \mathrm{M}$, the cell adhesion rates of the A549 cells were $86.58,75.40$ and $62.38 \%$ of that in the TPA-induced group, respectively $(\mathrm{P}<0.01)$. These data suggested that $\mathrm{Cal}$ inhibited the adhesion ability of the A549 cells to the cell matrix.

Cal inhibits A549 cell migration induced by TPA. The effect of Cal on TPA-induced A549 cell migration capability was estimated by a wound-healing assay and Transwell chamber assay. In the wound-healing assay (Fig. 2B and C), the cells treated with TPA covered $49.91 \%$ of the wound area, which was significantly higher than the untreated cells following incubation (13.31\%). The wound closure rates were 41.81, 36.62 and $22.98 \%$ following treatment with $\mathrm{Cal}$ at 20, 30 and $40 \mu \mathrm{M}$, respectively, which were significantly lower than that of the TPA-treated group $(\mathrm{P}<0.05)$.

Following $8 \mathrm{~h}$ Transwell chamber migration, the percentage of A549 cells that penetrated the membrane in the non-TPA-stimulated group was only $28 \%$. The percentages of cells that penetrated through the membrane following TPA treatment were significantly decreased when exposed to $\mathrm{Cal}$ concentrations of at 20,30 and $40 \mu \mathrm{M}$ to $72.46,52.46$ and $48.23 \%$, respectively, compared with the TPA-treated only group (Fig. 2D and $\mathrm{E} ; \mathrm{P}<0.01$ ).

Cal suppresses TPA-induced A549 cell invasion. A Transwell coated with Matrigel was used to determine the suppression of Cal on A549 cell invasion. As shown in Fig. 2F and G, the relative percentages of penetrated cells in the non-induced 
A

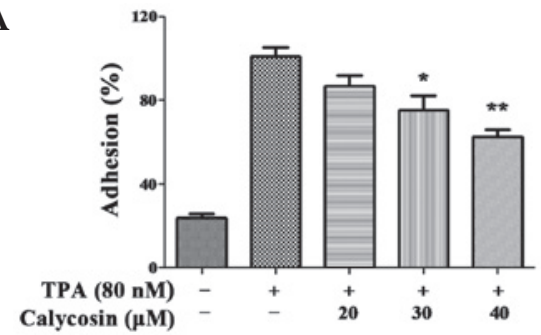

B

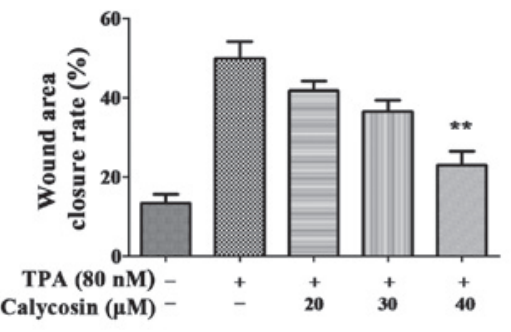

C

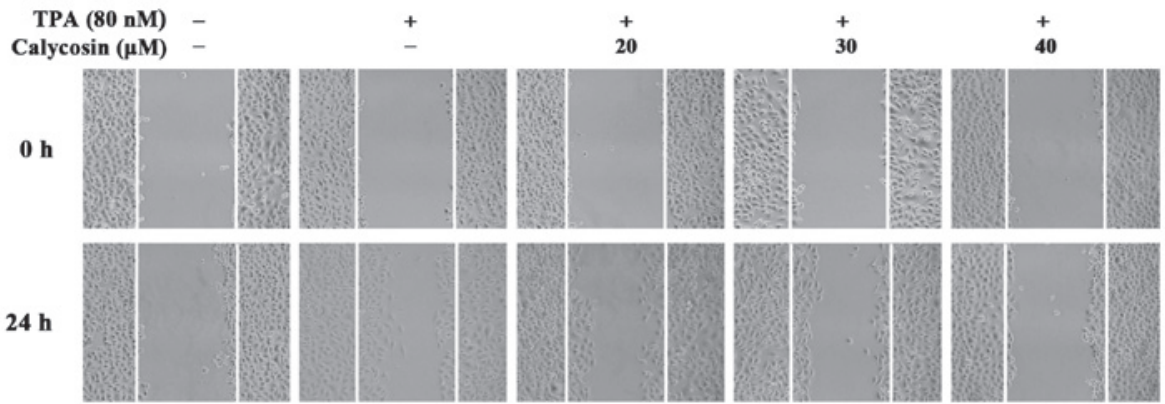

D

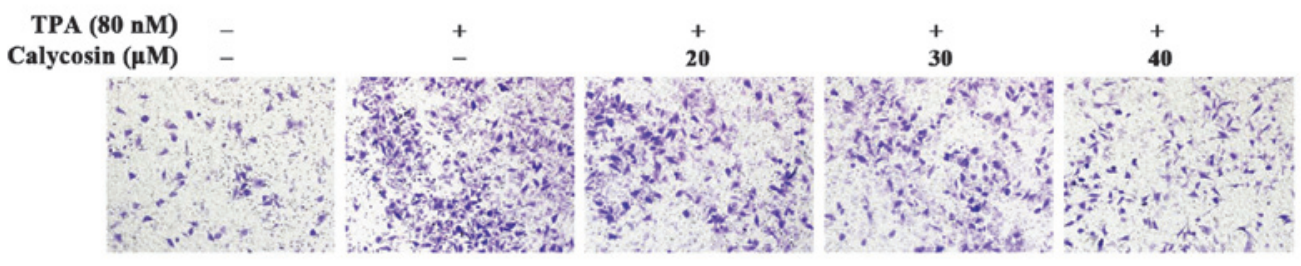

$\mathbf{E}$

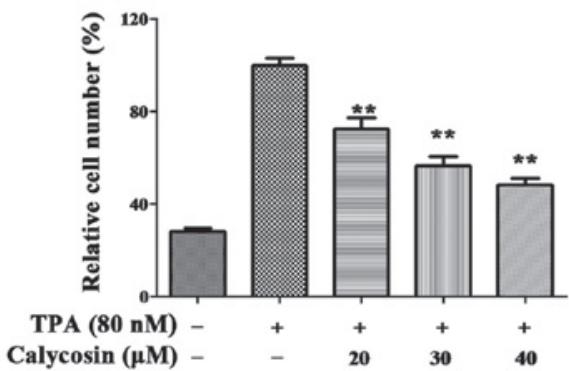

F
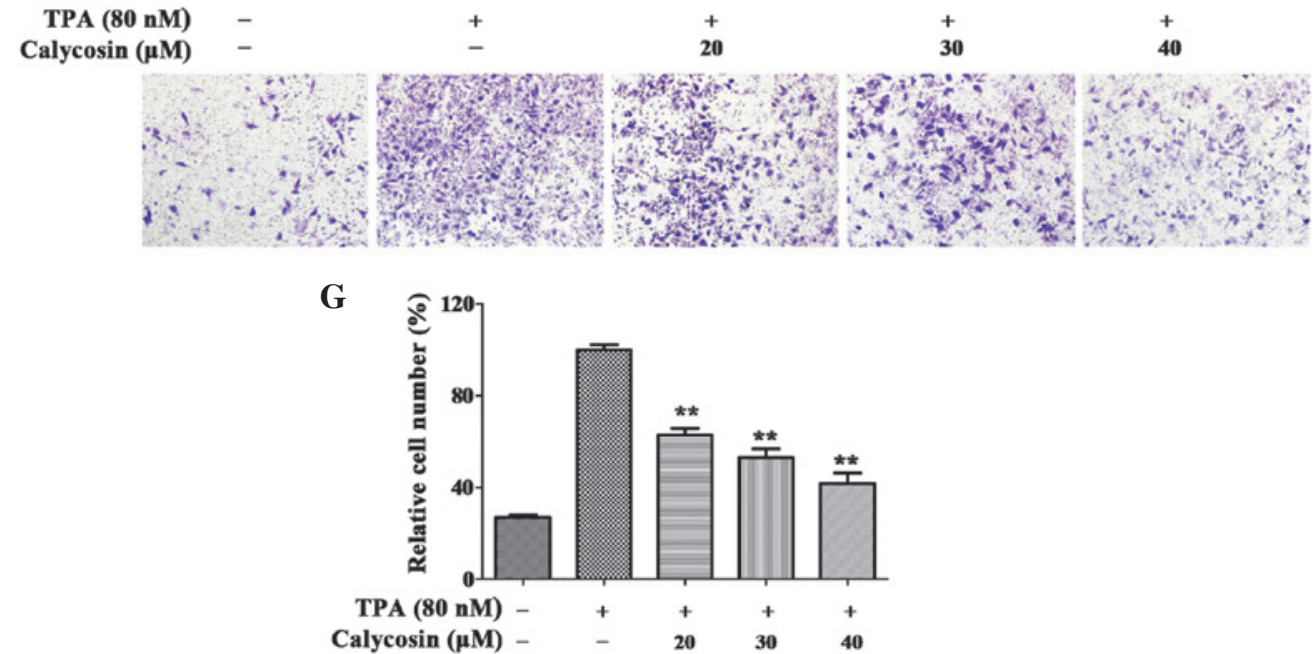

Figure 2. Effect of $\mathrm{Cal}$ on the adhesion, migration and invasion of TPA-induced A549 cells. The A549 cells were treated with $0,20,30$ or $40 \mu \mathrm{M} \mathrm{Cal,} \mathrm{in} \mathrm{the}$ presence or absence of TPA $(80 \mathrm{nM})$ for $24 \mathrm{~h}$, and were analyzed for (A) adherent ability and (B) wound healing. (C) Migration ability was determined by the closure rate of migrating cells at 24 h, vs. 0 h. (D) A549 cells were inoculated in Transwell chambers treated with Cal for $10 \mathrm{~h}$ to assess migration with an IX73 microscope and crystal violet staining (magnification, x100). (E) Permeated cells, compared with the TPA-induced group. (F) A549 cells were inoculated into Matrigel-coated Transwell chambers and treated with Cal for $24 \mathrm{~h}$ to assess cell invasiveness with an IX73 microscope following staining with crystal violet (magnification, x100). (G) Rate of cell invasion through the membrane, compared with the TPA-induced group. The results were obtained from triplicate experiments and are presented the mean \pm standard deviation $(n=3)$. $\mathrm{P} \leq 0.05$, vs. control; ${ }^{* *} \mathrm{P} \leq 0.01$ vs. control. Cal, calycosin; TPA, phorbol-12-myristate-13-acetate. 
A

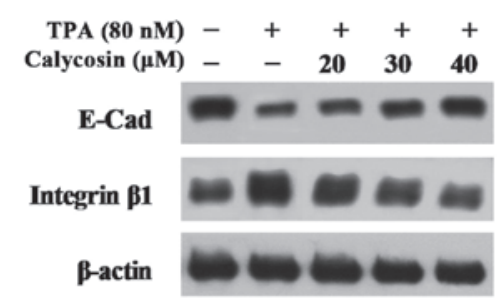

C

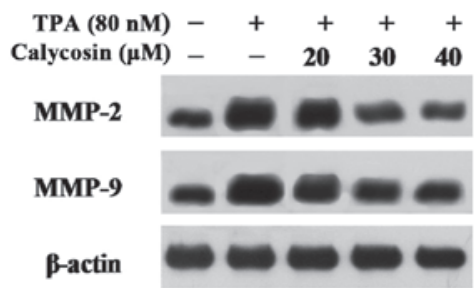

E

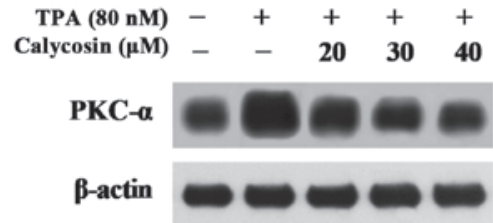

G

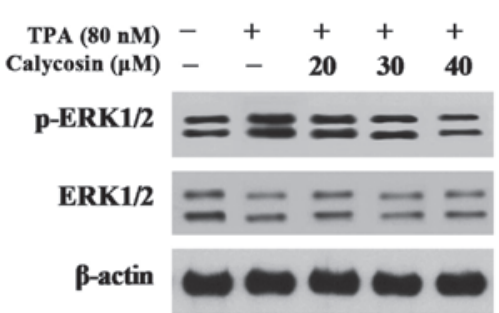

B

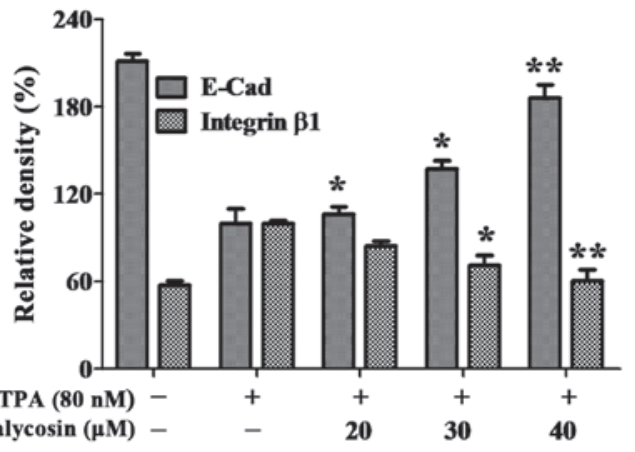

D

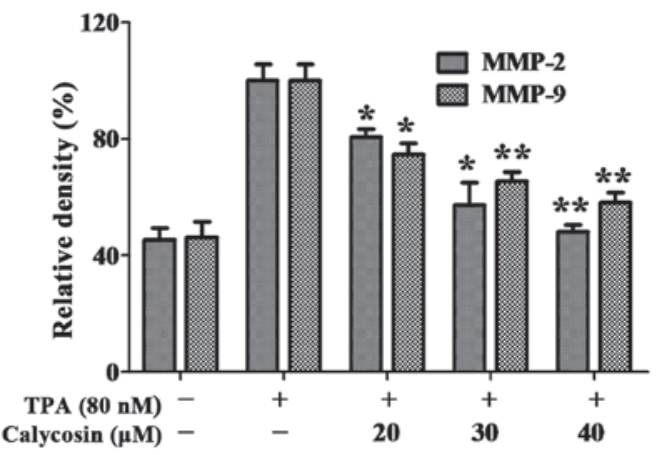

F

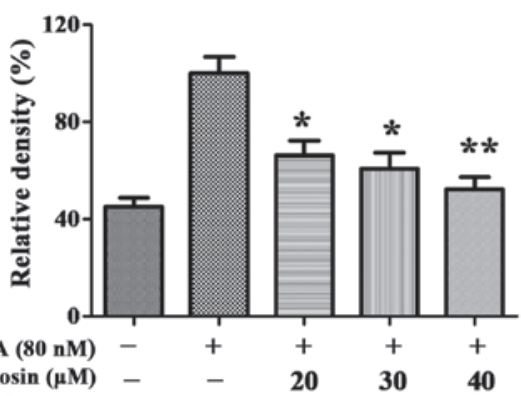

H

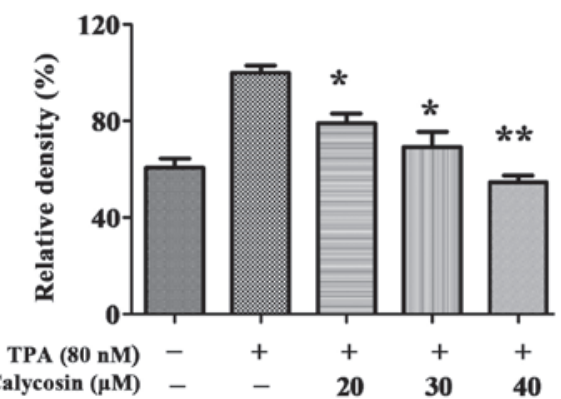

Figure 3. Effect of $\mathrm{Cal}$ on the expression levels of PKC- $\alpha$, p-ERK1/2, E-Cad, integrin $\beta 1$, MMP-2 and MMP-9. (A) A549 cells were treated with various concentrations $(0,20,30$ and $40 \mu \mathrm{M})$ of Cal in the presence or absence of TPA $(80 \mathrm{nM})$ for $24 \mathrm{~h}$, and then subjected to western blotting to analyze the protein levels of E-cad and integrin $\beta 1$. (B) Quantification of the protein level of E-cad and integrin $\beta 1$. (C) A549 cells were treated with various concentrations $(0,20$, 30 and $40 \mu \mathrm{M})$ of Cal in the presence or absence of TPA $(80 \mathrm{nM})$ for $24 \mathrm{~h}$, and then subjected to western blotting to analyze the protein levels of MMP-2 and MMP-9. (D) Quantification of the protein level of MMP-2 and MMP-9. (E) A549 cells were treated with various concentrations $(0,20,30$ and $40 \mu \mathrm{M})$ of Cal in the presence or absence of TPA $(80 \mathrm{nM})$ for $24 \mathrm{~h}$, and then subjected to western blotting to analyze the protein levels of PKC- $\alpha$. (F) Quantification of the protein level of PKC- $\alpha$. (G) A549 cells were treated with various concentrations $(0,20,30$ and $40 \mu \mathrm{M})$ of Cal in the presence or absence of TPA $(80 \mathrm{nM})$ for $24 \mathrm{~h}$, and then subjected to western blotting to analyze the protein levels of p-ERK1/2 and ERK1/2 (H) Quantification of the proteins level of p-ERK1/2 and ERK1/2. Values are presented as the mean \pm standard deviation of three independent experiments, performed in triplicate. ${ }^{*} \mathrm{P} \leq 0.05$ and ${ }^{* *} \mathrm{P} \leq 0.01$, vs. TPA-induced group. Cal, calycosin; TPA, phorbol-12-myristate-13-acetate; PCK, protein kinase C; p-ERK, phosphorylated extracellular signal-regulated kinase; E-Cad, E-cadherin; MMP, matrix metalloproteinase.

cell group increased between 26.69 and $100 \%$ when exposed to TPA. This results indicated that the invasion capability of the A549 cells induced by TPA was increased significantly, compared with control group. Compared with the TPA-treated only group, the increased number of penetrated cells innduced by TPA was significantly suppressed by $\mathrm{Cal}$ at concentrations of 20,30 and $40 \mu \mathrm{M}(62.72,52.99$ and $41.70 \%$, respectively) in a dose-dependent manner. $(\mathrm{P}<0.05)$. 
Cal reduces the mobility of A549 cells, suppresses the expression of integrin $\beta 1$ and increases the expression of E-cad. The increase in tumor cell mobility is important in the metastasis processes. The expression levels of E-Cad and integrin $\beta 1$, associated with cell migration, were detected in the present study using western blot analysis As shown in Fig. 3A and B, the relative expression level of E-Cad decreased between 221 and $100 \%$ when treated with TPA. However, the expression level was increased to $106.00,137.09$ and $185.94 \%$ following exposure to different concentrations of Cal for $24 \mathrm{~h}$. The relative activity of integrin $\beta 1$ activitiy was increased between 57.34 and $100 \%$ following stimulation with TPA. Cal inhibited this TPA-induced integrin $\beta 1$ activity to $84.50,71.04$ and $61.28 \%$ following exposure to 20,30 and $40 \mu \mathrm{M} \mathrm{Cal}$ for $24 \mathrm{~h}$. These results indicated that $\mathrm{Cal}$ suppressed the migration ability of the A549 cells by regulating the expression of E-Cad and reducing the expression of integrin $\beta 1$.

Cal inhibits extracellular matrix (ECM) degradation by suppressing the levels of MMP-2 and MMP-9. ECM degradation is crucial for tumor cell invasion, suggesting that MMPs are required. To clarify whether MMP-2 and MMP-9 were involved in the inhibition of invasion by $\mathrm{Cal}$, the expression levels of TPA-induced MMP-2 and MMP-9 affected by Cal were investigated using western blot analysis. As shown in Fig. 3C, the relative activities of MMP-2 increased between 45.48 and $100 \%$, compared with the TPA-only group. Cal inhibited the TPA-induced MMP-2 activities to 80.64, 57.40 and $48.14 \%$ following exposure to 20,30 and $40 \mu \mathrm{M} \mathrm{Cal}$, respectively for $24 \mathrm{~h}$. Similar results were observed for MMP-9, in which MMP-9 activity increased between 46.13 and 100\% following TPA stimulation, and decreased to $74.68,65.47$ and $58.10 \%$ with exposure to $\mathrm{Cal}$ at 20,30 and $40 \mu \mathrm{M}$, respectively, compared with TPA treatment only (Fig. 3D). These results suggested that Cal suppressed MMP-2 and MMP-9 to prevent ECM degradation and inhibit metastasis of the A549 cells.

Effect of Cal on the levels of PKC- $\alpha$ and ERK1/2 level in A549 cells. In order to further investigate the underlying mechanism, the effects of $\mathrm{Cal}$ on the expression levels of PKC- $\alpha$ and ERK1/2 were detected using western blot analysis. As shown in Fig. $3 \mathrm{E}$ and $\mathrm{F}$, a significant increase in the expression of PKC- $\alpha$ following TPA induction, and suppression of PKC- $\alpha$ following Cal treatment, were observed, in a dose-dependent manner, in the A549 cells. The expression of PKC- $\alpha$ without TPA induction was $44.99 \%$, compared with the A549 cells treated with TPA only, and the levels reduced to $66.30,60.34$ and $52.37 \%$ when the TPA-induced cells were exposed to 20 , 30 and $40 \mu \mathrm{M} \mathrm{Cal}$, respectively $(\mathrm{P}<0.01)$. The levels of p-ERK levels were $60.74 \%$ without TPA treatment and, following treatment with TPA, the phosphorylation of ERK1/2 increased significantly. These increased p-ERK levels were decreased to $79.27,69.46$ and $54.78 \%$ by 20,30 and $40 \mu \mathrm{M} \mathrm{Cal}$, respectively, in a dose-dependent manner (Fig. $3 \mathrm{G}$ and $\mathrm{H} ; \mathrm{P}<0.01$ ). The results of the PKC- $\alpha$ and ERK1/2 analyses demonstrated that $\mathrm{Cal}$ inhibited the activation of PKC- $\alpha$ and the expression of $\mathrm{p}-\mathrm{ERK} 1 / 2$.

Cal inhibits invasion and migration through the suppression of PKC- $\alpha$ in A549 cells. To further verify whether Cal inhibited A549 cell migration and invasion through the PKC- $\alpha$ pathway, the A549 cells were pretreated with the PKC- $\alpha$ inhibitor, AEB071 $(0.1 \mu \mathrm{M})$ for $30 \mathrm{~min}$, and then stimulated with $80 \mathrm{nM}$ TPA in the presence or absence of Cal $(30 \mu \mathrm{M})$ for $24 \mathrm{~h}$. As shown in Fig. 4A and B, the relative levels of PKC- $\alpha$ were reduced to 70.63 and $68.73 \%$ when treated with Cal or AEB071 alone, respectively, following induction by TPA. When the TPA-induced A549 cells were exposed to Cal combined with AEB071, the PKC- $\alpha$ level decreased significantly to $42.36 \%$.

As shown in Fig. 4C and D, AEB071 and Cal increased the levels of E-Cad reduced by TPA. Significant increases were observed with their co-treatment. Treatment with AEB071 or Cal alone reduced the expression levels of integrin $\beta 1$, MMP-2 and MMP-9. There were significant decreases in the expression levels of these proteins following co-treatment of AEB071 and $\mathrm{Cal}$, compared with their treatment alone.

In the Transwell invasion experiment, when the A549 cells were treated with Cal or AEB071 alone, the cell invasion ability was decreased to 59.78 and $48.60 \%$, compared with the TPA-induced group. The relative percentage of permeated cells was reduced to $37.92 \%$ when treated with Cal combined with AEB071 ( $\mathrm{P}<0.01$; Fig. 4E and $\mathrm{F})$. The results suggested that $\mathrm{Cal}$ inhibited the invasion of A549 cells by downregulating the expression levels of integrin $\beta 1$, MMP-2 and MMP-9, and elevating the expression of E-Cad, via suppression of the PKC- $\alpha$ pathway.

Cal inhibits invasion and migration of A549 cells through reducing the activation of ERK1/2 phosphorylation. In order to investigate whether Cal affected the downregulation of ERK1/2 phosphorylation, the ERK1/2 inhibitor, PD98059 $(25 \mu \mathrm{M})$, was used in the present study, and the protein expression levels of ERK1/2 and p-ERK1/2 in the A549 cells were detected using western blot analysis. The relative expression level of p-ERK1/2 was reduced to $51.42 \%$ and $38.73 \%$ following treatment with Cal or PD98059 alone, respectively, and the expression level was $26.13 \%$ following treatment with Cal and PD98059 combined (Fig. 5A and B).

As shown in Fig. 5C and D, the expression levels of integrin $\beta 1$, MMP-2 and MMP-9 were decreased markedly following co-treatment with PD98059 and Cal. Notably, these expression levels were lower than those observed following treatment with either Cal or PD98059 alone. In the TPA-induced A549 cells, a significant increase in the expression of E-Cad was observed in the Cal and PD98059 co-treatment group, compared with treatment with either alone.

The results of the invasion assay indicated that the relative percentage of permeated cells were significantly inhibited by Cal and PD98059 co-treatment to $31.84 \%$, compared with 61.29 and $48.80 \%$, respectively, following treatment with $\mathrm{Cal}$ or PD98059 alone (P<0.01; Fig. 5E and F). These results suggested that $\mathrm{Cal}$ inhibited the invasion of A549 cells by downregulating the expression levels of integrin $\beta 1$, MMP-2 and MMP-9, and elevating the expression of E-Cad via suppression of the ERK1/2 pathway.

\section{Discussion}

Lung cancer invasion and metastasis are the major reasons for the failure of surgery and radiotherapy to cure disease 
A

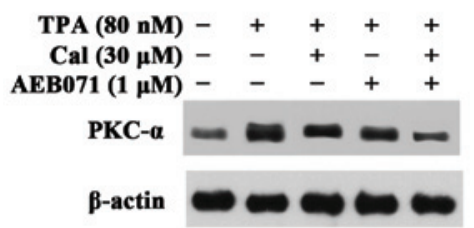

C

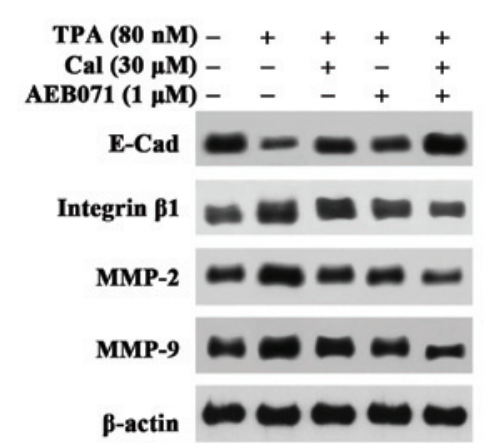

B

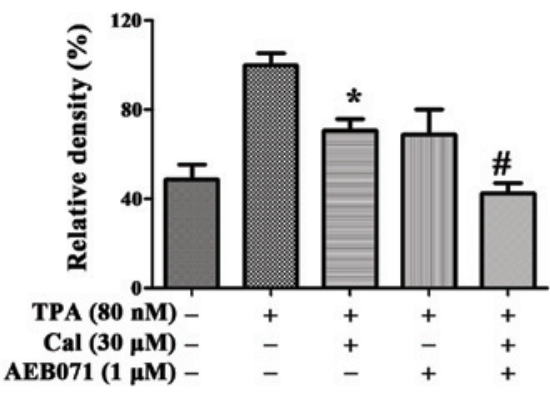

D

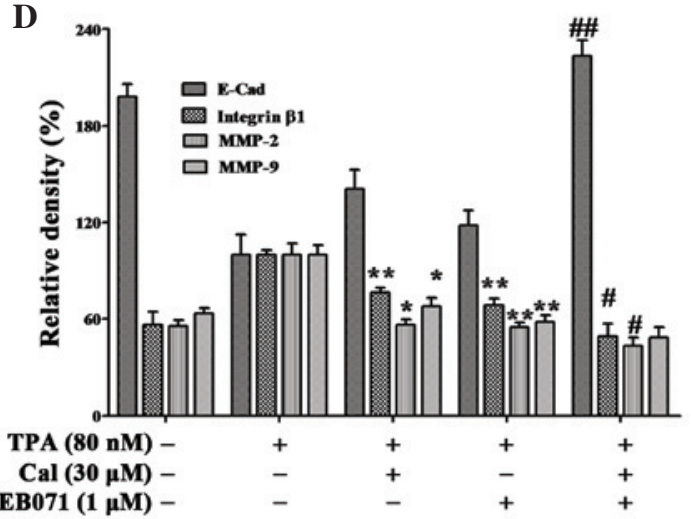

$\mathbf{E}$
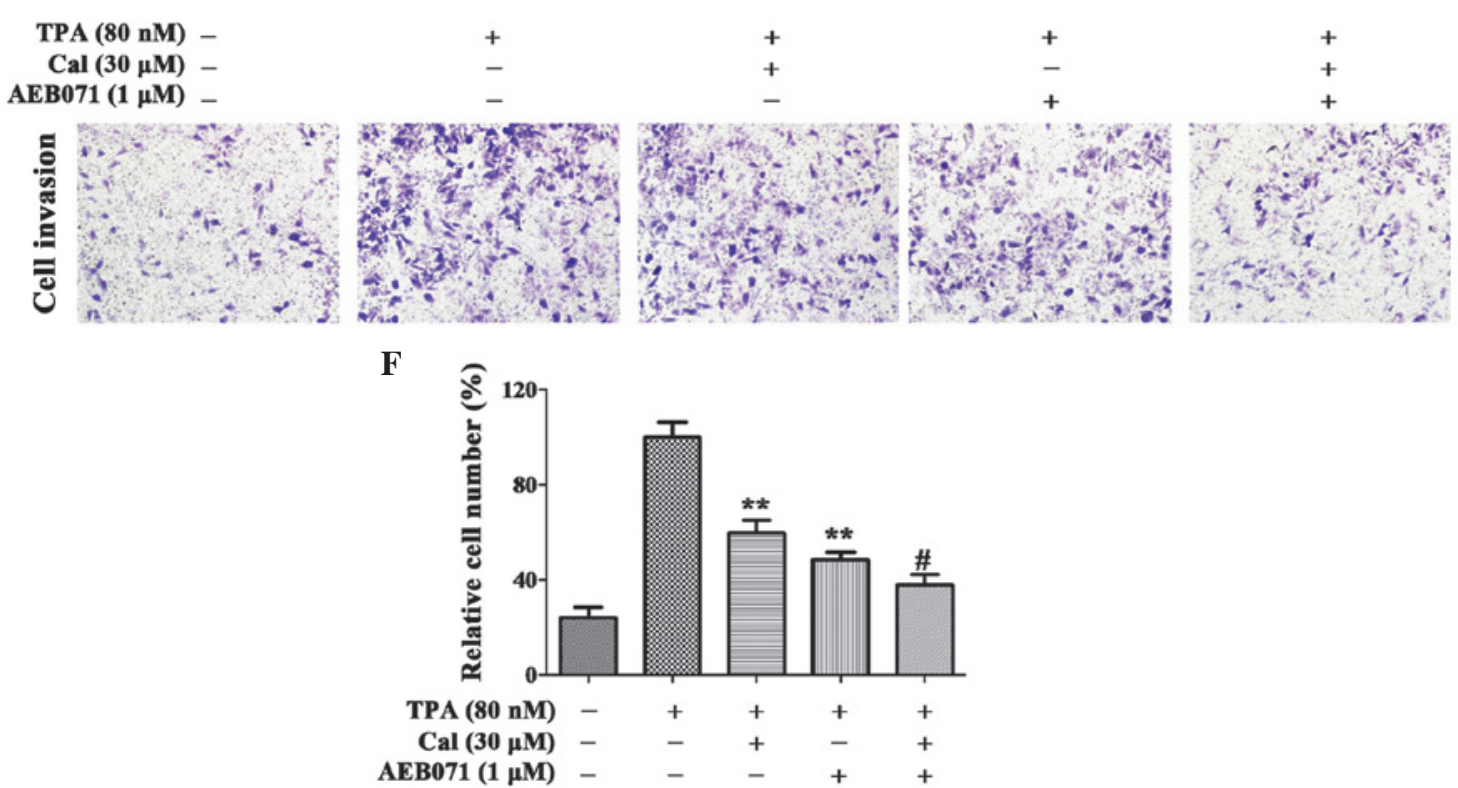

Figure 4. Cal inhibits invasion by suppressing PKC- $\alpha$. (A and B) Cells were pretreated with AEB071 $(0.1 \mu \mathrm{M})$ for 30 min and then incubated in the presence or absence of Cal $(30 \mu \mathrm{M})$ for $24 \mathrm{~h}$. The A549 cells were then subjected to western blotting to analyze the protein levels of PKC- $\alpha$ and (C and D) E-Cad, integrin $\beta 1$, MMP-2 and MMP-9. (E) Cells were pretreated with AEB071 $(0.1 \mu \mathrm{M})$ for 30 min and then incubated in the presence or absence of Cal $(30 \mu \mathrm{M})$ for $24 \mathrm{~h}$. Cellular invasiveness was measured using a Transwell invasion assay and an IX73 microscope following staining with crystal violet (magnification, x100). (F) Invasion rate is expressed as a percentage of the TPA-induced group. Values are presented as the mean \pm standard deviation of three independent experiments, performed in triplicate. ${ }^{*} \mathrm{P} \leq 0.05$ and ${ }^{* *} \mathrm{P} \leq 0.01$, vs. TPA-induced group. ${ }^{*} \mathrm{P} \leq 0.05$ and ${ }^{\# \#} \mathrm{P} \leq 0.01$, vs. Cal ${ }^{+}$group. Cal, calycosin; TPA, phorbol-12-myristate-13-acetate; PCK, protein kinase C; E-Cad, E-cadherin; MMP, matrix metalloproteinase.

and for relapse following systemic therapy (30). Therefore, chemical materials, which have an effect on the treatment of metastasis have an important impact on lung cancer mortality rates. Studies have demonstrated that $\mathrm{Cal}$ reduces AGE-induced macrophage migration and adhesion to human umbilical vein endothelial cells $(31,32)$. However, the antimetastatic effect and the underlying mechanisms in A549 cells remain to be elucidated. The present study revealed that $\mathrm{Cal}$ inhibited the migration and invasion of A549 lung cancer cells via suppression of the
PKC- $\alpha /$ ERK $1 / 2$ signaling pathways to regulate the expression levels of migration and invasion-associated proteins, including E-Cad, integrin $\beta 1$ and MMPs.

Cancer cell proliferation and apoptosis are physiologic processes, which are important in tumor development (33). In clinical cancer therapy, cell proliferation inhibition and apoptosis induction in tumor tissue remain the optimum treatment strategy (34). Cal has been reported to inhibit proliferation and induce apoptosis in osteosarcoma and MCF-7 cells $(35,36)$. In 


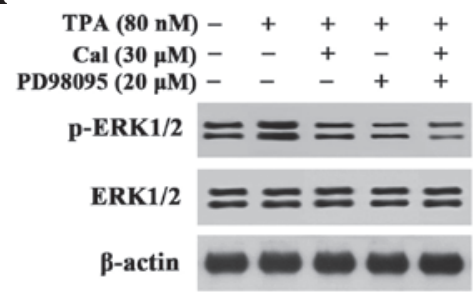

C

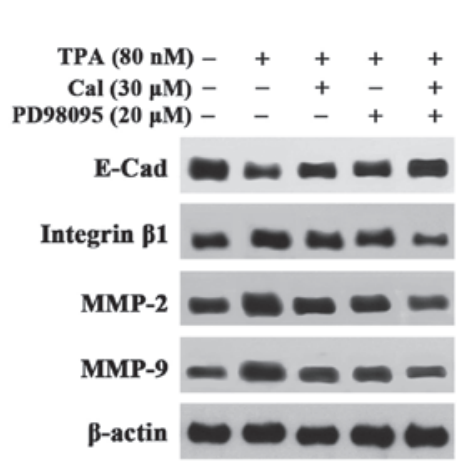

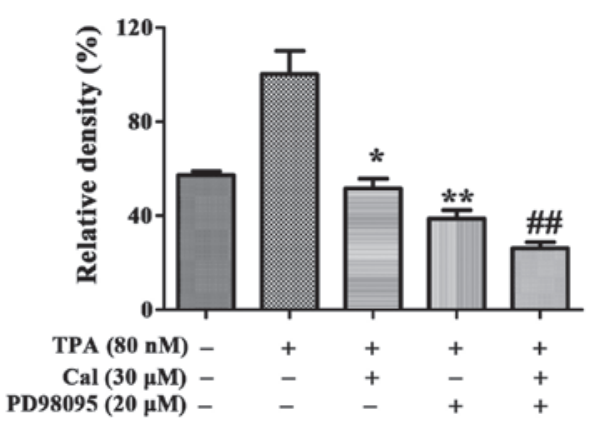

D

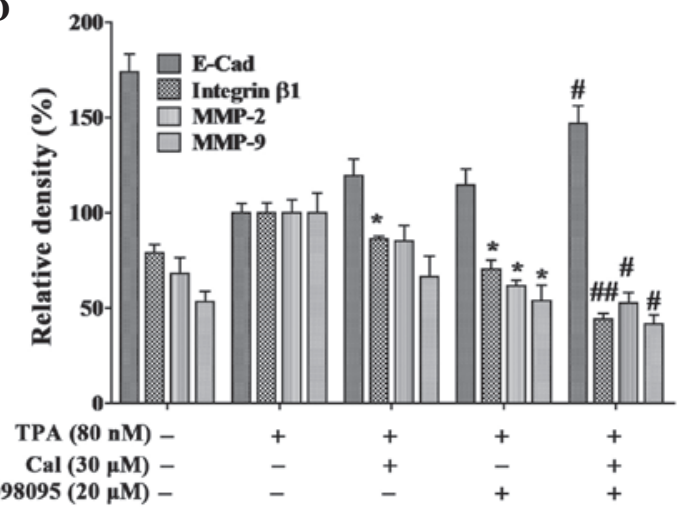

$\mathbf{E}$
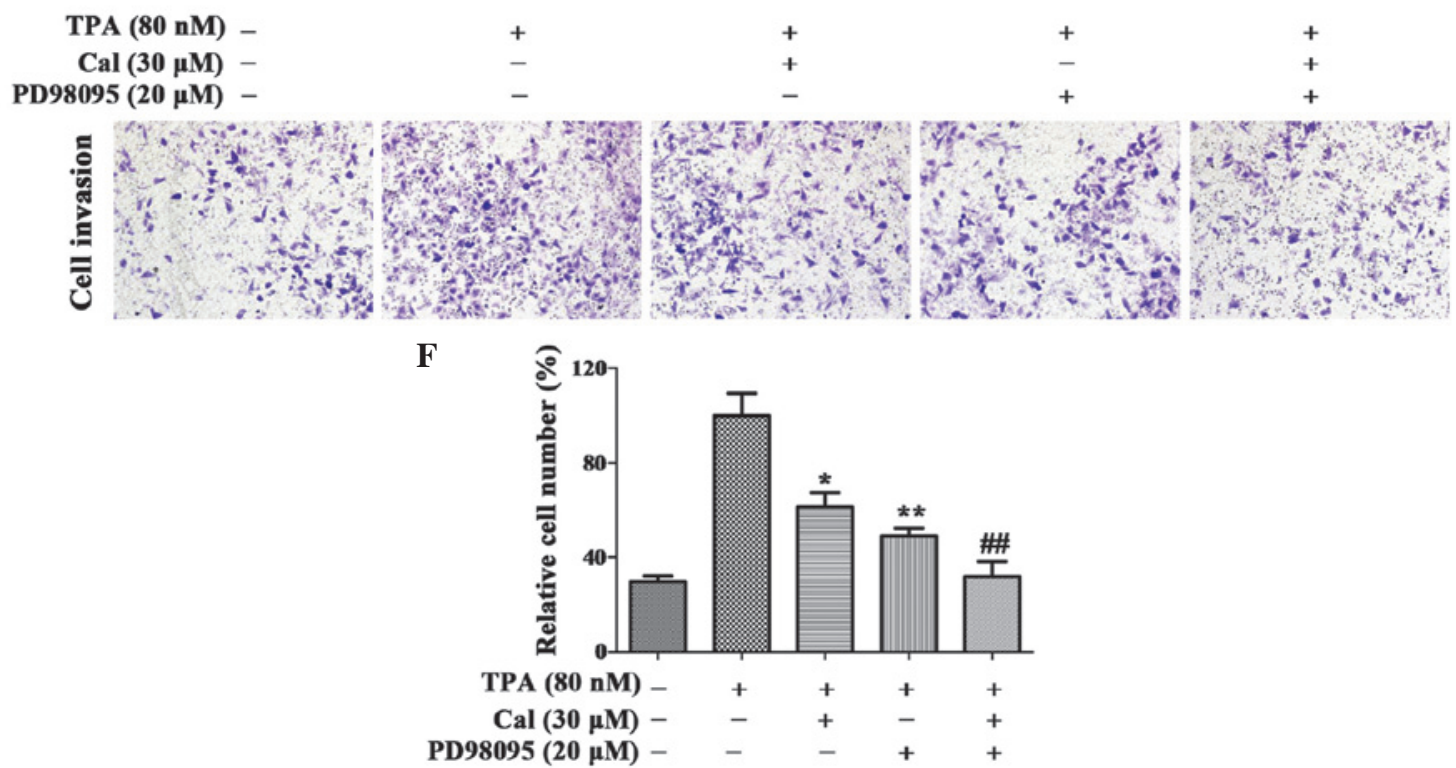

Figure 5. Cal inhibits invasion by suppressing ERK1/2 phosphorylation. (A and B) Cells were pretreated with PD98059 (20 $\mu \mathrm{M})$ for 30 min and then incubated in the presence or absence of $\mathrm{Cal}(30 \mu \mathrm{M})$ for $24 \mathrm{~h}$. A549 cells were then subjected to western blotting to analyze the protein levels of p-ERK1/2 and ERK1/2 and (C and D) E-Cad, integrin 31 , MMP-2 and MMP-9. (E) Cells were pretreated with PD98059 $(20 \mu \mathrm{M})$ for 30 min and then incubated in the presence or absence of $\mathrm{Cal}(30 \mu \mathrm{M})$ for $24 \mathrm{~h}$. Cell invasiveness was measured using a Transwell invasion assay and an IX73 microscope following staining with crystal violet (magnification, x100). (F) Invasion rate is expressed as a percentage of the TPA-induced group. Values are presented as the mean \pm standard deviation of three independent experiments, performed in triplicate. ${ }^{*} \mathrm{P} \leq 0.05$ and ${ }^{* *} \mathrm{P} \leq 0.01$, vs. TPA-induced group; ${ }^{*} \mathrm{P} \leq 0.05$ and ${ }^{\# \#} \mathrm{P} \leq 0.01$, vs. Cal ${ }^{+}$group. Cal, calycosin; TPA, phorbol-12-myristate-13-acetate; PCK, protein kinase C; p-ERK, phosphorylated extracellular signal-regulated kinase; E-Cad, E-cadherin; MMP, matrix metalloproteinase.

the present study, Cal inhibited the proliferation of A549 cells in a dose-dependent manner. The percentage of apoptotic cells, determined using Annexin V-FITC/PI staining revealed that, following Cal treatment for $24 \mathrm{~h}$, the proportion of apoptotic cells increased markedly.

Cancer cell migration and invasion are associated with adhesion, not only with the cell, but also with the ECM (37).
The levels of proteins, including E-Cad and integrin $\beta 1$ are associated with the adhesion ability of cancer cells. E-Cad is a key protein involved in cell-cell adhesion, and loss of E-Cad can reduce cell adhesion in the tissue and promote invasion and metastasis in several types of epithelial tumor $(38,39)$. The level of E-Cad can be suppressed by TPA in Caco-2 cells and results in the disassembly of adherin junctions (40). Integrin 
$\beta 1$-mediated adhesion, migration and metastasis are induced by activating intracellular signaling pathways, including the ERK and phosphoinositide 3-kinase signaling pathways (41). Integrin $\beta 1$ is involved in lung cancer invasion and metastasis and can be inhibited by suppressing the ERK1/2 signaling pathway (42). In the present study, Cal significantly inhibited A549 cell migration stimulated by TPA via upregulating the expression of E-Cad and downregulating the expression of integrin $\beta 1$.

Cell invasion requires proteolysis of ECM components and transmigration through the ECM (43). ECM degradation allows cancer cells to invade into blood or lymphatic system and spread to distant tissues and organs. In these processes, the expression of proteolytic enzymes, including, MMPs and particularly MMP-2 and MMP-9 are crucial for ECM degradation (44). The overexpression of MMP-2 and MMP-9 induced by TPA result in a significant increase in invasion and may be suppressed by the PKC $\alpha / E R K / N F-\kappa B$ pathway (45). Treatment with Cal significantly inhibited cell adhesion and invasion by downregulating the expression levels of MMP-2 and MMP-9, according to the results of the present study.

The expression levels of the E-Cad, integrin $\beta 1$, MMP-2 and MMP-9 proteinases can be regulated by multiple signaling pathways, including PKC- $\alpha$ (46). Overexpression of PKC- $\alpha$, stimulated by TPA, can promote tumor cell metastasis via upregulating the expression of MMPs and downregulating the expression of E-cad $(47,48)$. The reduction in the stimulated expression of PKC- $\alpha$ by TPA with inhibitors may reduce the motility and invasion of A549 cells, as well as the expression levels of MMPs (49). In present study, when exposed to Cal, the overexpression of PKC- $\alpha$ induced by TPA decreased in a dose-dependent manner. AEB071, an effective PKC- $\alpha$ inhibitor, can be used to verify whether PKC- $\alpha$ was involved in cancer cell migration and invasion (50). In the present study, treatment with AEB071 significantly inhibited migration and invasion by reducing the protein expression levels of integrin $\beta 1, \mathrm{MMP}-2$ and MMP-9, and increasing the protein expression of E-Cad. The results suggested that the Cal inhibited the invasion of A549 cells by downregulating integrin $\beta 1$, MMP-2 and MMP-9, and elevating E-Cad, via suppression of the PKC- $\alpha$ pathway.

The overexpression of PKC- $\alpha$ can activate downstream signaling pathway, including ERK1/2, and alter the expression of E-Cad, integrin $\beta 1$, MMP-2 and MMP-9, which leads to tumor migration and invasion (51). Chemicals inhibiting ERK1/2 phosphorylation may restrain cancer cell migration and invasion (52). The phosphorylation of ERK1/2 in cells treated with Cal was significantly reduced, compared with the TPA-induced cells in the present study. The ERK1/2 inhibitor, PD98059, is an effective method to verify whether the ERK1/2 signaling is pathway involved in cancer cell invasion (53). Combined with PD98059, Cal significantly suppressed migration and invasion, downregulated the protein expression levels of integrin $\beta 1$, MMP-2 and MMP-9, and increased the expression of E-Cad in the present study. Therefore, Cal inhibited the invasion of the A549 cells by downregulating the expression levels of integrin $\beta 1$, MMP-2 and MMP-9, and elevating the expression of E-Cad, via suppression of the ERK1/2 pathway.

In conclusion, the results of the present study demonstrated that $\mathrm{Cal}$ inhibited the proliferation, invasion and migration of A549 cells by suppressing the PKC- $\alpha /$ ERK1/2 signaling pathway. The results offer novel insight into the molecular mechanisms of Cal in lung cancer therapy. Therefore, Cal may be a useful compound for the inhibition of metastasis in lung cancer.

\section{Acknowledgements}

This study is supported by the Suzhou Science and Technology Program (grant. no. ZXY2012009) and the College Graduate Research and Innovation Project of Jiangsu Province (grant. no. CXLX13_599).

\section{References}

1. Siegel R, Ma J, Zou Z and Jemal A: Cancer statistics, 2014. CA Cancer J Clin 64: 9-29, 2014

2. DeSantis CE, Lin CC, Mariotto AB, Siegel RL, Stein KD, Kramer JL, Alteri R, Robbins AS and Jemal A: Cancer treatment and survivorship statistics. CA Cancer J Clin 64: 252-271, 2014.

3. Shiono S, Kanauchi N, Yanagawa N, Abiko M and Sato T: Stage II-IV lung cancer cases with lymphovascular invasion relapse within 2 years after surgery. Gen Thorac Cardiovasc Surg 62: $112-118,2014$.

4. Lai CS, Boshoff C, Falzon M and Lee SM: Complete response to erlotinib treatment in brain metastases from recurrent NSCLC. Thorax 61: 91, 2006

5. Huo XW, Li SN, Shi TT, Suo AL, Ruan ZP and Yao Y: Tripartite motif 16 inhibits epithelial-mesenchymal transition and metastasis by down-regulating sonic hedgehog pathway in non-small cell lung cancer cells. BBRC 460: 1021, 2015.

6. Jo E, Park SJ, Choi YS, Jeon WK and Kim BC: Kaempferol suppresses transforming growth factor- $\beta 1$-induced epithelial-tomesenchymal transition and migration of A549 lung cancer cells by inhibiting Akt1-mediated phosphorylation of Smad3 at threonine-179. Neoplasia 17: 525, 2015.

7. Liu ZL, Zhu WR, Zhou WC, Ying HF, Zheng L, Guo YB Chen JX and Shen XH: Traditional Chinese medicinal herbs combined with epidermal growth factor receptor tyrosine kinase inhibitor for advanced non-small cell lung cancer: A systematic review and meta-analysis. J Integr Med 12: 346-358, 2014.

8. Yang XB, Wu WY, Long SQ, Deng $\mathrm{H}$ and Pan ZQ: Effect of gefitinib plus Chinese herbal medicine (CHM) in patients with advanced non-small-cell lung cancer: a retrospective case-control study. Complement Ther Med 22: 1010-1018, 2014.

9. Zhou ZY, Xu L, Li HG, Tian JH, Jiao LJ, You SF, Han ZF, Jiang Y, Guo HR and Liu H: Chemotherapy in conjunction with traditional Chinese medicine for survival of elderly patients with advanced non-small-cell lung cancer: protocol for a randomized double-blind controlled trial. J Integr Med 12: $175-181,2014$

10. Ma X, Zhang T, Wei Y, Tu P, Chen Y and Ito Y: Preparative isolation and purification of calycosin from Astragalus membranaceus Bge. var. mongholicus (Bge.) Hsiao by high-speed counter-current chromatography. J Chromatogr A 962: 243-247, 2002.

11. Gao J, Liu ZJ, Chen T and Zhao D: Pharmaceutical properties of calycosin, the major bioactive isoflavonoid in the dry root extract of Radix astragali. Pharm Biol 52: 1217-1222, 2014.

12. Zhang D, Wang S, Zhu L, Tian Y, Wang H, Zhuang Y, Li Y and Wang D: Profiling of hepatocellular carcinoma cell cycle regulating genes targeted by calycosin. Biomed Res Int 2013: 317926, 2013.

13. Wang Y, Dong X, Li Z, Wang W, Tian J and Chen J: Downregulated RASD1 and upregulated miR-375 are involved in protective effects of calycosin on cerebral ischemia/reperfusion rats. J Neurol Sci 339: 144-148, 2014.

14. Li W, Sun YN, Yan XT, Yang SY, Kim S, Lee YM, Koh YS and Kim YH: Flavonoids from Astragalus membranaceus and their inhibitory effects on LPS-stimulated pro-inflammatory cytokine production in bone marrow-derived dendritic cells. Arch Pharm Res 37: 186-192, 2014.

15. Liu Y, He J, Chen X, Li J, Shen M, Yu W, Yang Y and Xiao Z: The Proapoptotic Effect of Formononetin in Human Osteosarcoma Cells: Involvement of Inactivation of ERK and Akt Pathways. Cell Physiol Biochem 34: 637-645, 2014. 
16. Tian J, Duan YX, Bei CY and Chen J: Calycosin induces apoptosis by upregulation of RASD1 in human breast cancer cells MCF-7. Horm Metab Res 45: 593-598, 2013.

17. Huang KP: Role of protein kinase $\mathrm{C}$ in cellular regulation. Biofactors 2: 171-178, 1990.

18. Konopatskaya O and Poole AW: Protein kinase Calpha: Disease regulator and therapeutic target. Trends Pharmacol Sci 31: 8-14, 2010.

19. Hwang YP, Yun HJ, Kim HG, Han EH, Choi JH, Chung YC and Jeong HG: Suppression of phorbol-12-myristate-13-acetate-induced tumor cell invasion by piperine via the inhibition of PKC $\alpha /$ ERK1/2-dependent matrix metalloproteinase-9 expression. Toxicol Lett 203: 9-19, 2011.

20. Lin CW, Shen SC, Chien CC, Yang LY, Shia LT and Chen YC: 12-O-tetradecanoylphorbol-13-acetate-induced invasion/migration of glioblastoma cells through activating PKCalpha/ERK/NF-kappaB-dependent MMP-9 expression. J Cell Physiol 225: 472-481, 2010.

21. Yang MY, Hsu LS, Peng CH, Shi YS, Wu CH and Wang CJ: Polyphenol-rich extracts from Solanum nigrum attenuated PKC alpha-mediated migration and invasion of hepatocellular carcinoma cells. J Agric Food Chem 58: 5806-5814, 2010.

22. Lau GT, Huang H, Lin SM and Leung LK: Butein downregulates phorbol 12-myristate 13-acetate-induced COX-2 transcriptional activity in cancerous and non-cancerous breast cells. Eur J Pharmacol 648: 24-30, 2010.

23. Roskoski R Jr: ERK1/2 MAP kinases: Structure, function and regulation. Pharmacol Res 66: 105-143, 2012.

24. Zhou X, Liu Y, You J, Zhang H, Zhang X and Ye L: Myosin light-chain kinase contributes to the proliferation and migration of breast cancer cells through cross-talk with activated ERK1/2. Cancer Lett 270: 312-327, 2008.

25. Tang JY, Li S, Li ZH, Zhang ZJ, Hu G, Cheang LC, Alex D, Hoi MP, Kwan YW, Chan SW, et al: Calycosin promotes angiogenesis involving estrogen receptor and mitogen-activated protein kinase (MAPK) signaling pathway in zebrafish and HUVEC. PLoS One 5: e11822, 2010.

26. Chen J, Hou R, Zhang X, Ye Y, Wang Y and Tian J: Calycosin suppresses breast cancer cell growth via ER $\beta$-dependent regulation of IGF-1R, p38 MAPK and PI3K/Akt pathways. PLoS One 9: e91245, 2014.

27. Liao YC, Shih YW, Chao CH, Lee XY and Chiang TA: Involvement of the ERK signaling pathway in fisetin reduces invasion and migration in the human lung cancer cell line A549. J Agric Food Chem 57: 8933-8941, 2009.

28. Shieh JM, Chiang TA, Chang WT, Chao CH, Lee YC, Huang GY, Shih YX and Shih YW: Plumbagin inhibits TPA-induced MMP-2 and u-PA expressions by reducing binding activities of NF-kappaB and AP-1 via ERK signaling pathway in A549 human lung cancer cells. Mol Cell Biochem 335: 181-193, 2010.

29. Liu B, Wang G, Yang J, Pan X, Yang Z and Zang L: Berberine inhibits human hepatoma cell invasion without cytotoxicity in healthy hepatocytes. PLoS One 6: e21416, 2011.

30. Noda M and Takahashi C: Recklessness as a hallmark of aggressive cancer. Cancer Sci 98: 1659-1665, 2007.

31. Xu Y, Feng L, Wang S, Zhu Q, Zheng Z, Xiang P, He B and Tang D: Calycosin protects HUVECs from advanced glycation end products-induced macrophage infiltration. J Ethnopharmacol 137: 359-370, 2011.

32. Xu Y, Feng L, Wang S, Zhu Q, Lin J, Lou C, Xiang P, He B, Zheng Z, Tang D and Zuo G: Phytoestrogen calycosin-7-O- $\beta$-D-glucop yranoside ameliorates advanced glycation end products-induced HUVEC damage. J Cell Biochem 112: 2953-2965, 2011.

33. Lokeshwar BL, Selzer MG, Zhu BQ, Block NL and Golub LM: Inhibition of cell proliferation, invasion, tumor growth and metastasis by an oral non-antimicrobial tetracycline analog (COL-3) in a metastatic prostate cancer model. Int J Cancer 98: 297-309, 2002.

34. Hu C, Yi C, Hao Z, Cao S, Li H, Shao X, Zhang J, Qiao T and Fan D: The effect of somatostatin and SSTR3 on proliferation and apoptosis of gastric cancer cells. Cancer Biol Ther 3: 726-730, 2004.

35. Qiu R, Ma G, Zheng C, Qiu X, Li X, Li X, Mo J, Li Z, Liu Y, Mo L, et al: Antineoplastic effect of calycosin on osteosarcoma through inducing apoptosis showing in vitro and in vivo investigations. Exp Mol Pathol 97: 17-22, 2014.
36. Chen J, Zhao X, Ye Y, Wang Y and Tian J: Estrogen receptor beta-mediated proliferative inhibition and apoptosis in human breast cancer by calycosin and formononetin. Cell Physiol Biochem 32: 1790-1797, 2013

37. Trepat X, Chen $\mathrm{Z}$ and Jacobson K: Cell migration. Compr Physiol 2: 2369-2392, 2012.

38. Canel M, Serrels A, Frame MC and Brunton VG: E-cadherin-integrin crosstalk in cancer invasion and metastasis. J Cell Sci 126: 393-401, 2013.

39. Rodriguez-Teja M, Gronau JH, Minamidate A, Darby S, Gaughan L, Robson C, Mauri F, Waxman J and Sturge J: Survival outcome and EMT suppression mediated by a lectin domain interaction of endo180 and CD147. Mol Cancer Res 13: 538-547, 2015.

40. Barbosa LA, Goto-Silva L, Redondo PA, Oliveira S, Montesano G, De Souza W and Morgado-Díaz JA: TPA-induced signal transduction: A link between PKC and EGFR signaling modulates the assembly of intercellular junctions in Caco- 2 cells. Cell Tissue Res 312: 319-331, 2003.

41. Hou M, Cui J, Liu J, Liu F, Jiang R, Liu K, Wang Y, Yin L, Liu W and Yu B: Angiopoietin-like 4 confers resistance to hypoxia/serum deprivation-induced apoptosis through PI3K/Akt and ERK1/2 signaling pathways in mesenchymal stem cells. PLoS One 9: e85808, 2014.

42. Wang $\mathrm{H}, \mathrm{Wu} \mathrm{C}$, Wan S, Zhang H, Zhou S and Liu G: Shikonin attenuates lung cancer cell adhesion to extracellular matrix and metastasis by inhibiting integrin $\beta 1$ expression and the ERK1/2 signaling pathway. Toxicology 308: 104-112, 2013.

43. Willis AL, Sabeh F, Li XY and Weiss SJ: Extracellular matrix determinants and the regulation of cancer cell invasion stratagems. J Microsc 251: 250-260, 2013.

44. Chen K, Zhang S, Ji Y, Li J, An P, Ren H, Liang R, Yang J and Li Z: Baicalein inhibits the invasion and metastatic capabilities of hepatocellular carcinoma cells via down-regulation of the ERK pathway. PLoS One 8: e72927, 2013.

45. Shi MD, Shih YW, Lee YS, Cheng YF and Tsai LY: Suppression of 12-O-tetradecanoylphorbol-13-acetate-induced MCF-7 breast adenocarcinoma cells invasion/migration by $\alpha$-tomatine through activating PKC $\alpha / \mathrm{ERK} / \mathrm{NF}-\kappa \mathrm{B}-$ dependent MMP-2/MMP-9 expressions. Cell Biochem Biophys 66: 161-174, 2013.

46. Wang Y, Yang H, Liu H, Huang J and Song X: Effect of staurosporine on the mobility and invasiveness of lung adenocarcinoma A549 cells: An in vitro study. BMC Cancer 9: 174-186, 2009.

47. Park SH, Kim JH, Lee DH, Kang JW, Song, Oh SR and Yoon DY: Luteolin 8-C- $\beta$-fucopyranoside inhibits invasion and suppresses TPA-induced MMP-9 and IL-8 via ERK/AP-1 and ERK/NF- $\kappa B$ signaling in MCF-7 breast cancer cells. Biochimie 951: 2082-2090, 2013.

48. Zucchini-Pascal N, Peyre L and Rahmani R: Crosstalk between beta-catenin and snail in the induction of epithelial to mesenchymal transition in hepatocarcinoma: Role of the ERK1/2 pathway. Int J Mol Sci 1410: 20768-20792, 2013.

49. Chen CC,ChenJJandChou CY:Proteinkinasecalphabutnotp44/42 mitogen-activated protein kinase, $\mathrm{p} 38$, or c-Jun $\mathrm{NH}(2)$-terminal kinase is required for intercellular adhesion molecule-1 expression mediated by interleukin-1beta: Involvement of sequential activation of tyrosine kinase, nuclear factor-kappaB-inducing kinase and IkappaB kinase 2. Mol Pharmacol 58: 1479-1489, 2000.

50. Capsoni F, Ongari AM, Reali E, Bosè F and Altomare GF: The protein kinase C inhibitor AEB071 (sotrastaurin) modulates migration and superoxide anion production by human neutrophils in vitro. Int J Immunopathol Pharmacol 25: 617-626, 2012.

51. Cheng X, Gu J, Zhang M, Yuan J, Zhao B, Jiang J and Jia X: Astragaloside IV inhibits migration and invasion in human lung cancer A549 cells via regulating PKC- $\alpha$-ERK1/2-NF- $\kappa \mathrm{B}$ pathway. Int Immunopharmacol 23: 304-313, 2014.

52. Ren W, Liu Y, Wan S, Fei C, Wang W, Chen Y, Zhang Z, Wang T, Wang J,Zhou L, et al: BMP9 inhibits proliferation and metastasis of HER2-positive SK-BR-3 breast cancer cells through ERK1/2 and PI3K/AKT pathways. PLoS One 9: e96816, 2014.

53. Karroum A, Mirshahi P, Benabbou N, Faussat AM, Soria J, Therwath A, Mirshahi M and Hatmi M: Matrix metalloproteinase-9 is required for tubular network formation and migration of resistant breast cancer cells MCF-7 through PKC and ERK1/2 signalling pathways. Cancer Lett 295: 242-251, 2010. 